\title{
Research on the Relationship Between Government Subsidies and High-quality Development of Enterprises
}

\author{
Haijuan Xie*, Miao Yu, Hong Zhao
}

\author{
Guilin University of Electronic Technology, Guilin, Guangxi, China \\ *Corresponding author.Email: 394771293@qq.com
}

\begin{abstract}
This article takes China's listed manufacturing companies from 2014 to 2019 as the research object, studies the relationship between government subsidies and high-quality development of enterprises, and introduces the ownership structure to establish interaction items, and explores the impact of the ownership structure on the relationship between the two. Research indicates: There is a negative correlation between government subsidies and the high-quality development of enterprises, and the concentration of equity will positively regulate the inhibitory effect of government subsidies on the high-quality development of China's enterprises. The degree of equity checks and balances will inhibit the negative relationship between the two.
\end{abstract}

Keywords: Government Subsidies, High-quality Development, Ownership Structure.

\section{INTRODUCTION}

The 19th National Congress of the Communist Party of China clearly pointed out that our economy has transformed from a stage of rapid growth to a stage of high-quality development. China is striving to promote high-quality development in all walks of life and promote high-quality economic development. Especially in 2020, due to the impact of COVID-19, China's development faces unprecedented risks and challenges. It is even more important to promote high-quality development of enterprises and grasp the important strategic opportunity period for China's development.

The profitability of Chinese enterprises is generally low, and it is difficult for enterprises themselves to undertake all the requirements for high-quality development. Therefore, the government needs to play the necessary intervention and incentive role. At this time, government support is particularly important. Among many government support policies, government subsidy is an important macro-control tool adopted by the government to achieve the established goals. In recent years, the Chinese government has continuously increased the government subsidy funds for enterprises, with nearly 100 billion yuan in government subsidies every year. The flow of funds to listed companies will inevitably have an important impact on the high-quality development of enterprises. The realization of highquality development of enterprises not only requires government subsidies, but also requires the enterprises themselves to have corresponding governance mechanisms. The effective combination of internal and external can help enterprises the purpose of enterprise development.

Therefore, the influence mechanism of government subsidies for enterprises on the high-quality development of enterprises has become an issue worthy of in-depth study.

\section{LITERATURE REVIEW AND RESEARCH HYPOTHESIS}

\subsection{Government Subsidies and High-quality Development of Enterprises}

Government subsidies have a restraining effect the development quality of Chinese manufacturing enterprises. First, as a kind of free transfer payment (Lina Zhu et al., 2018) [1], government subsidies will make enterprises lack the motivation for R\&D and innovation while it makes enterprises obtain excess profits (Xue Yang et al., 2020) [2]. And this will reduce the total factor productivity of enterprises to a certain extent and inhibit the enterprise development quality. Second, some companies in order to obtain government subsidies, some manufacturing companies may conduct "Rent-Seeking" and establish political connections with local governments, etc (Shukuan Zhao et al., 2017) [3]. On the 
one hand, it will lead to the occupation of resources. On the other hand, enterprises relying on "Rent-Seeking" behavior to obtain excessive subsidies may also cause them to overinvest in low-efficiency projects, which will damage the efficiency of the company's production factors and hinder the high-quality development of the enterprise. Third, government subsidies will cause the government to interfere too much in the production activities of enterprises (Qi $\mathrm{Su}$ et al., 2018) [4]. The government pays more attention to the social performance brought about by subsidies. It is not its ultimate goal to increase the total factor productivity of enterprises. Excessive government subsidies will induce manufacturing enterprises to adopt catering behaviors, which are contrary to increasing total factor productivity. In summary, this article proposes the following hypotheses:

H1: Government subsidies are negatively related to the high-quality development of enterprises.

\subsection{The Moderating Effect of Equity Concentration}

Concentration of equity is an important manifestation of the characteristics of the company's equity structure. The high degree of equity concentration reflects the actual control ability of the company's major shareholders. First, although the existence of large shareholders can alleviate the agency problem between operators and shareholders to a certain extent (Li Zhang, Yanyan Gao,2019) [5], with the relative concentration of ownership, the large shareholders of enterprises will "Appropriate" the others. Second, the concentration of equity will bring about the concentration of corresponding risks, and major shareholders have to bear higher risks. Due to the risk aversion of major shareholders, higher risks may cause major shareholders to be reluctant to engage in excessive investment activities with riskier investors. Third, concentration of corporate equity is too high, although the enterprise management obtains the benefits, but it damages the interests of the stakeholders, so that the expected effect of government subsidies will not be satisfied. In summary, this article proposes the following hypotheses:

$\mathrm{H} 2$ : The concentration of equity has a moderating effect on the relationship between government subsidies and the high-quality development of manufacturing enterprises.

\subsection{The Moderating Effect of Equity Checks and Balances}

Equity checks and balances can alleviate the second type of agency problem in corporate governance. First, equity checks and balances can effectively alleviate the agency cost problems faced by enterprises, prevent major shareholders from colluding with senior management, and curb managers' pursuit of private interests. Second, compared with "One Share Dominates", only a balanced shareholding structure can achieve the most efficient level of supervision. Equity checks and balances are conducive to the introduction of an external supervision mechanism to strengthen the supervision of major shareholders and effectively alleviate caused by the inconsistent interests of various shareholders. Equity checks and balances are conducive to the introduction of an external supervision mechanism, strengthen the supervision of major shareholders, and effectively alleviate the impact of inconsistent interests among shareholders. Third, the equity check and balance system will pay more attention to protecting the interests of all shareholders. Shareholders will make more scientific decisions so that government subsidies can be used more scientifically. In summary, this article proposes the following hypotheses:

H3: The equity checks and balances has a moderating effect on the relationship between government subsidies and the high-quality development of manufacturing enterprises.

\section{RESEARCH DESIGN}

\subsection{Data Source}

This article selects 2014-2019 listed China's manufacturing companies as the research object, and does the following processing on the data: (1) exclude the financial industry and enterprises specially treated by ST or * ST; (2) excluding the enterprises with incomplete disclosure of government subsidy data; (3) eliminating enterprises with incomplete data. Through screening, 4014 samples were obtained. In the research process, All financial data and government subsidy data are from CSMAR and Wind database.

\subsection{Variable Definition}

(1) Explained variable: Enterprise high quality development (TFP). Therefore, this paper uses the existing research methods and takes TFP as a substitute variable. Referring to the practice of Xiao-Dong $\mathrm{Lu}$ and Yu-Jun Lian (2012) [6], this paper uses total factor productivity to measure the high-quality development index of enterprises.

(2) Explanatory variable: Government subsidy (GOV). This paper takes the ratio of the total government subsidies received by enterprises to the business income of enterprises as the observed value of government subsidies.

(3) Regulatory variables: Ownership Structure. Generally speaking, the ownership structure includes two dimensions: the concentration of ownership (OC) and the degree of balance of ownership (ER). This article uses the ratio of the largest shareholder's shareholding as an 
alternative indicator of the concentration of equity (OC), and "(shareholding ratio of the top ten largest shareholders-Shareholding ratio of the largest shareholder / Shareholding ratio of the largest shareholder)" as the Alternative indicators of checks and balances (ER).

(4) Control variables: Taking into account the existence of other factors that may affect the high-quality development of enterprises by government subsidies and drawing on previous research literature, this article selects net sales margin (Snp), corporate profitability (Pro), management expense ratio (Adm), selling expense ratio (Oer), the proportion of independent directors (Roid), and the year (Year) are used as control variables.

The detailed index setting principles of the variables in Table 1 are as follows:

Table 1. Main Variable Definition Table

\begin{tabular}{|l|l|l|l|}
\hline Variable Type & Variable Name & $\begin{array}{l}\text { Variable } \\
\text { Symbol }\end{array}$ & Variable Metric \\
\hline $\begin{array}{l}\text { Explained } \\
\text { variable }\end{array}$ & Enterprise high quality development & TFP & Measuring total factor productivity with LP method \\
\hline $\begin{array}{l}\text { Explanatory } \\
\text { variable }\end{array}$ & Government subsidy & GOV & Total government subsidies /Business income \\
\hline \multirow{3}{*}{$\begin{array}{l}\text { Regulatory } \\
\text { variables }\end{array}$} & Ownership Structure & OC & The ratio of the largest shareholder's shareholding \\
\cline { 2 - 4 } & Sales Margin & ER & $\begin{array}{l}\text { shareholding ratio of the top ten largest shareholders- } \\
\text { Shareholding ratio of the largest shareholder / } \\
\text { Shareholding ratio of the largest shareholder }\end{array}$ \\
\cline { 2 - 4 } & Enterprise profitability variable & Pro & Net profit / average net assets \\
\cline { 2 - 4 } Control & Administrative expense ratio & Adm & Administrative expenses/Total assets \\
\cline { 2 - 4 } variable & Selling Expense Ratio & Oer & Selling expenses/Total assets \\
\cline { 2 - 4 } & Proportion of Independent Directors & Roid & Independent Director/All Directors \\
\cline { 2 - 4 } & Years & Industry & Annual Dummy Variable \\
\hline
\end{tabular}

\subsection{Measurement Model}

In order to verify the relationship between manufacturing government subsidies and the highquality development of enterprises, this paper constructs a test model as follows:

$$
\begin{aligned}
& \text { TFP }_{i, t}=\alpha_{0}+\beta_{1} \text { GOV }_{i, t}+\beta_{2} \text { Snp }_{i, t}+\beta_{3} \text { Pro }_{i, t} \\
& +\beta_{4} \text { Adm }_{i,}+\beta_{5} \text { Oer }_{i, t}+\beta_{6} \text { Roid }_{i, t}+\sum \text { Year }+\varepsilon i, t
\end{aligned}
$$

In order to test the moderating effect of the ownership structure on the relationship between government subsidies and high-quality development of enterprises from the perspective of internal control, model (2) and model (3) are established:

$$
\begin{aligned}
& \text { TFP }_{i, t}=\alpha_{0}+\beta_{1} \text { GOV }_{i, t}+\delta_{1} \text { OC }_{i, t}+a G O V_{i, t} \times O C_{i, t} \\
& +\beta_{2} \text { Snp }_{i, t}+\beta_{3} \text { Pro }_{i, t}+\beta_{4} A_{d m_{i, t}}+\beta_{5} \text { Oer }_{i, t} \\
& +\beta_{6} \text { Roid }_{i, t}+\sum \text { Year }+\varepsilon_{i, t} \\
& \text { TFP }_{i, t}=\alpha_{0}+\beta_{1} \text { GOV }_{i, t}+\delta_{2} \text { ER }_{i, t}+b G O V_{i, t} \times E R_{i, t} \\
& +\beta_{2} \text { Snp }_{i, t}+\beta_{3} \text { Pro }_{i, t}+\beta_{4} \text { Adm }_{i, t}+\beta_{5} \text { Oer }_{i, t} \\
& +\beta_{6} \text { Roid }_{i, t}+\sum \text { Year }+\varepsilon_{i, t}
\end{aligned}
$$

\section{EMPIRICAL ANALYSIS}

\subsection{Descriptive Statistics and Analysis}

It can be seen from table 2 that the maximum value of total factor productivity is 10.5555 , the minimum value is 6.1526 , and the standard deviation is 0.8353 , which indicates that there are obvious differences in the development quality of different enterprises. The median of total factor productivity is7.9601, which shows that the development quality of most manufacturing enterprises in China is not high. The maximum government subsidy intensity is 0.0836 , indicating that the scale of government subsidies is different, and the scale of subsidies for individual enterprises is far beyond the average level. The remaining variables basically conform to the normal distribution.

\subsection{Empirical Test}

From the results in Table 3, it can be seen that the regression coefficient between government subsidies and high-quality development of enterprises is-14.9089, which is significant at the $1 \%$ level, indicating that the higher the government subsidies, the less conducive to the high-quality development of enterprises. This confirms the hypothesis H1. 
Table 2. Descriptive Statistics

\begin{tabular}{ccccccc}
\hline \hline Variables & $\mathrm{N}$ & Maximum & Minimum & Mean & Median & Std. Dev. \\
\hline TFP & 4014 & 10.5555 & 6.1526 & 8.0207 & 7.9601 & 0.8353 \\
GOV & 4014 & 0.0836 & 0.0002 & 0.0112 & 0.0072 & 0.0133 \\
OC & 4014 & 67.7422 & 8.4774 & 31.5658 & 29.6602 & 13.2506 \\
ER & 4014 & 4.1651 & 0.0776 & 1.0259 & 0.8024 & 0.8103 \\
Snp & 4014 & 0.3793 & -0.6838 & 0.0707 & 0.0720 & 0.1345 \\
Pro & 4014 & 0.2993 & -0.4415 & 0.0651 & 0.0651 & 0.0995 \\
Adm & 4014 & 0.1409 & 0.0129 & 0.0552 & 0.0515 & 0.0251 \\
Oer & 4014 & 0.3100 & 0.0023 & 0.0496 & 0.0289 & 0.0579 \\
Roid & 4014 & 0.5714 & 0.3333 & 0.3772 & 0.3333 & 0.0545 \\
\hline \hline
\end{tabular}

The test results are listed in Table 3. Model 2 tests the moderating effect of equity concentration. The regression results show that the interaction coefficient is -0.3199 , and it is significant at the $1 \%$ level, indicating that the concentration of equity has promoted the negative impact of government subsidies, and the moderating effect exists, which supports the research hypothesis $\mathrm{H} 2$ of this article.
Model 3 tests the moderating effect of equity checks and balances. The regression results show that the interaction coefficient is 3.2996 , and it is significant at the $1 \%$ level. It shows that equity checks and balances inhibit the negative impact of government subsidies, and the moderating effect is established, thus supporting the research hypothesis $\mathrm{H} 3$ of this article.

Table 3. Return results of government subsidies and high-quality development of enterprises

\begin{tabular}{cccc}
\hline \hline Variables & Model 1 & Model 2 & Model 3 \\
\cline { 2 - 4 } GOV & TFP & TFP & $-19.078^{* * *}$ \\
OC & $-14.9089^{* * *}$ & $-5.8314^{* * *}$ & \\
GOV×OC & & $0.0089^{* * * *}$ & $-0.0809^{* * *}$ \\
ER & & $-0.3199^{* * *}$ & $3.2996^{* * * *}$ \\
GOV×ER & & & $-3.7811^{* * *}$ \\
Snp & & & $6.3322^{* * *}$ \\
Pro & $7.9601^{* * *}$ & $-3.7317^{* * *}$ & $-5.0764^{* * *}$ \\
Adm & $6.4438^{* * *}$ & $6.2008^{* * *}$ & $0.6944^{* * *}$ \\
Oer & $-5.1138^{* * *}$ & $-4.8352^{* * *}$ & $-0.6094^{* * *}$ \\
Roid & $0.6416^{* * *}$ & $0.61478^{* * *}$ & Control \\
Year & $-0.6164^{* * *}$ & $-0.6513^{* * *}$ & 4014 \\
$\mathrm{~N}$ & Control & Control & 0.3495 \\
Adj $\mathrm{R}^{2}$ & 4014 & 4014 & 0.3569 \\
\hline \hline
\end{tabular}

Note: $* \mathrm{P}<0.01, * \mathrm{P}<0.05, * \mathrm{P}<0.1$, the same below.

\section{CONCLUSIONS AND RECOMMENDATIONS}

The study found that excessive government subsidies will inhibit the high-quality development of enterprises, and this negative relationship is affected by ownership structure, among which equity concentration plays a positive role in regulating the relationship between government subsidies and high-quality development of enterprises, And the degree of equity checks and balances will weaken the inhibitory effect of government subsidies on the high-quality development of enterprises.

This article mainly has the following two aspects of enlightenment: 1 . The issuance of government subsidies is to play its active role. The government should select the recipient enterprises according to certain policy standards; constantly adjust the granting of subsidy funds, so as to urge the subsidized enterprises to justify the subsidy funds. 2 . The establishment of an equity check- and-balance mechanism can not only maintain the relative concentration of equity, but also suppress the speculative behavior of major shareholders through supervision, thereby promoting the high-quality development of manufacturing enterprises.

\section{ACKNOWLEDGMENTS}

Fund Projects: Graduate Education Innovation Project of Guilin University of Electronic Technology(2020YCXS066), Guangxi Philosophy and Social Science Planning Research Project (20FGL027).

\section{REFERENCES}

[1] Lina Zhu, Xuan He, Renwei Shao, Jun Ma. Will Officials' Turnover Affect Enterprises' Financial Subsidies? An Empirical Research Based on 
Chinese Family Firms [J]. Journal of Finance and Economics, 2018, 44(10): 138-152.

[2] Xue Yang, Yucheng He, Cheng Liu. Impact of government subsidies on total factor productivity of Chinese agricultural listed companies: Based on panel threshold model [J]. Journal of Hunan Agricultural University (Social Sciences), 2020, 21(03): 59-66.

[3] Shukuan Zhao, Qi Qi, Jinfeng Zhang. A Study on the Impact of Government Subsidies on Corporate Innovation from the Perspective of Rent-seeking- Based on the Data of China's Listed Companies [J]. East China Economic Management, 2017, 31(12): 5-10+2.

[4] Qi Su, Yueqi Yu, Dan Li. A Study on the Impact of Corporate Innovation Capability on Sustainable Development Capability_ Based on the Moderating Role of Government Subsidy [J]. East China Economic Management, 2018,32(11):112117.

[5] Li Zhang, Yanyan Gao. An Empirical Study on the Relationship between Actual Controllers, Institutional Investors and Innovation InputAnalysis of Data from Listed Companies on my country's Growth Enterprise Market [J]. Commercial Accounting, 2019(16): 44-48.

[6] Xiaodong Lu, Yujun Lian. Estimation of Total Factor Productivity of Chinese Industrial Enterprises:1999-2007 [J]. China Economic Quarterly, 2012, 11(02): 541-558. 